\title{
IMPLEMENTASI LINGKUNGAN KERJA RAMAH PEREMPUAN DAN IMPLIKASINYA TERHADAP PERAN SERTA PEKERJA PEREMPUAN DENGAN STUDI KASUS RUMAH SAKIT KHUSUS IBU DAN ANAK KOTA BANDUNG
}

\author{
Maulida Ayu \\ Universitas Islam Negeri (UIN) Syarif Hidayatullah Jakarta \\ E-mail: maulidaayusp@gmail.com
}

\begin{abstract}
Abstrak: Penelitian ini membahas tentang implementasi lingkungan kerja ramah perempuan dan implikasinya terhadap peran serta pekerja perempuan. Penelitian dilakukan di pada tanggal 20-21 September 2015 dengan dengan subjek penelitian adalah pekerja wanita di Rumah Sakit Khusus Ibu dan Anak (RSKIA) Kota Bandung. Penelitian menggunakan pendekatan kualitatif dengan metode deskriptif analitik. Dari hasil penelitian didapatkan hasil bahwa terdapat hal-hal yang sudah diimplementasikan oleh RSKIA Kota Bandung untuk menciptakan lingkungan kerja ramah perempuan yaitu terdapat wanita memperoleh hak dan kesempatan yang sama dalam organisasi, memperoleh fasilitas ramah perempuan dan banyak positif lainnya sehingga mampu mengkompensasi beban kerja serta meningkatkan produktifitas dan performa karyawan.
\end{abstract}

Kata kunci : lingkungan kerja, ramah perempuan, RSKIA

\section{PENDAHULUAN}

Pertumbuhan dan perkembangan dunia secara global berdampak pada berbagai aspek salah satunya adalah partisipasi perempuan dalam lapangan pekerjaan (UN Research Institute for Social Development, 2010). Saat ini, perempuan memiliki peranan besar dalam sektor ekonomi di Indonesia. Bahkan ada sektor pekerjaan tertentu yang didominasi oleh perempuan. Di sisi lain, mereka masih dibebankan tugas domestik yang tidak ringan diantaranya dalam perawatan anak. Kebanyakan masyarakat memandang pekerja wanita sebagai sosok yang harus dapat melakukan pekerjaan domestik dan karirnya secara bersamaan (UNWomen, 2015). Berdasarkan laporan BPS 2015, perbandingan jumlah penduduk perempuan dan laki-laki adalah hampir sama. Populasi penduduk tertinggi adalah di provinsi Jawa Barat yaitu sebesar 46 juta jiwa dengan kepadatan penduduk tertinggi kedua setelah DKI Jakarta dan mayoritas tinggal di kota. Penduduk
Jawa Barat juga memiliki jumlah angkatan kerja tertinggi di Indonesia yang diiringi dengan tingginya jumlah tenaga kerja perempuan (BPS, 2015).

United Nation Entity for Gender Equality and The Empowerment of Women dalam laporannya Progress of Women World 20152016 menjelaskan tentang 10 prioritas aksi publik untuk transformasi kerja perempuan serta kebijakan pemerintah yang salah satu tujuannya untuk menciptakan lingkungan kerja ramah perempuan (UNWomen, 2015). Hal ini juga didukung oleh beberapa konvensi ILO tentang pekerja perempuan diantaranya tentang diskriminasi, upah, perlindungan maternal, waktu kerja serta fasilitas yang harus disediakan tempat kerja kepada pekerjanya. Indonesia juga telah meratifikasi beberapa peraturan ILO tersebut dan telah membuat kebijakan-kebijakan demi mendukung tercipatnya hal tersebut (ILO, 2015). Diantaranya dengan melakukan evaluasi dan penghargaan bagi tempat kerja (swasta dan 
pemerintah) pembina perempuan terbaik (PERMEN PP\&PA No. 7 tahun 2014). Tempat kerja yang termasuk kriteria ini diantaranya adalah mempekerjakan lebih dari 50 pekerja perempuan serta tidak disarankan bagi perusahaan rokok, perusahaan susu formula, dan perusahaan lain yang memproduksi barang atau jasa yang dilarang oleh Pemerintah.

Instansi pelayanan publik sudah seharusnya memberikan contoh yang baik dalam menciptakan lingkungan kerja ramah perempuan (AIMI, 2013). Rumah Sakit Khusus Ibu dan Anak Kota Bandung merupakan salah satu instansi pelayanan publik yang mayoritas pengguna jasa (domestic unpaid workers) dan pemberi jasanya (paid workers) adalah kaum perempuan.

Dengan alasan-alasan tersebut, penulis melakukan penelitian tentang Implementasi Lingkungan Kerja Ramah Perempuan dan Implikasinya Terhadap Peran Serta Pekerja Perempuan dengan Studi Kasus Rumah Sakit Khusus Ibu dan Anak Kota Bandung.

\section{METODE PENELITIAN}

Metode penelitian yang digunakan adalah penelitian deskriptif kualititatif dengan studi kasus, yaitu sebuah pencarian fakta dengan interpretasi yang tepat (Molly, 2011). Penelitian kualitatif yaitu suatu pendekatan penelitian yang menggunakan data berupa kalimat tertulis atau lisan, perilaku, fenomena, peristiwa-peristiwa dan pengetahuan atau obyek studi. Pendekatan ini menitikberatkan pada pemahaman, pemikiran dan persepsi peneliti. Metode penelitian kualitatif adalah metode penelitian yang digunakan untuk meneliti pada kondisi obyek yang alamiah, (sebagai lawannya adalah eksperimen) di mana peneliti adalah sebagai instrumen kunci (Sugiyono, 2008)

Teknik pengumpulan data menggunakan multi sumber bukti (triangulasi)artinya teknik pengumpulan data yang bersifat menggabungkan dari berbagai teknik pengumpulan data dan sumber data yang telah ada. Subjek dari penelitian ini adalah pekerja wanita RSKIA Kota Bandung, Jawa Barat dengan metode pengambilan sampel acak sederhana dan diambil selama 2 hari pada tanggal 20-21 September 2015. Pengumpulan data mengacu berdasarkan pertanyaan dan kriteria pada PERMEN PP\&PA No. 7 tahun 2014.

Analisis data pada penelitian ini adalah induktif kualitatif. Tahap ini terdiri dari tahap analisis data kualitatif yang dikemukakan dalam konsep yang diberikan oleh Spradley. Spradley membagi analisis data dalam penelitian kualitatif berdasarkan tahapan dalam penelitian kualitatif. Tahapan tersebut bisa susun secara sistematis sebagaimana berikut:

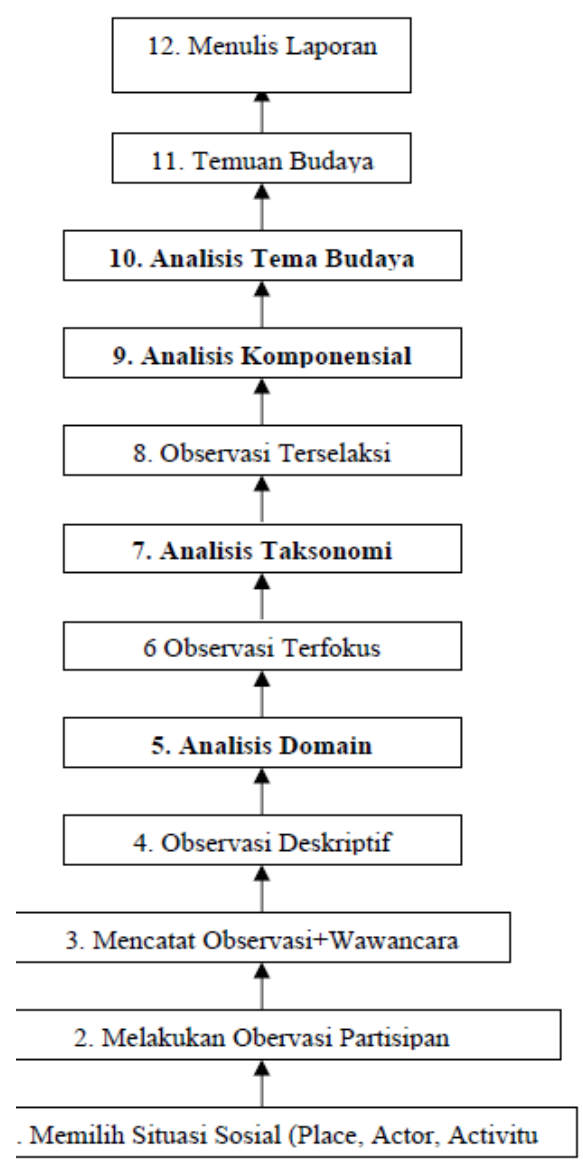

Gambar 2. Tahapan Analisis Data 
Teknik pengujian keabsahan data kualitatif yang dilakukan pada penelitian ini meliputi:

1. Uji Kredibilitas (Validitas Internal)

Kredibilitas data atau kepercayaan terhadap data hasil penelitian kualitatif antara lain sebagai berikut :

a. Perpanjangan Pengamatan

Dalam penelitian ini diperpanjang sampai dengan beberapa kali, yaitu wawancara dilakukan lebih dari sekali. Wawancara tidak hanya dilakukan dengan subyek, tetapi juga dilakukan dengan beberapa informan (significant other). Begitu juga pada tahap observasi yang diulang sebanyak 3 kali, melalui observasi intens. Artinya observasi dilakukan dengan waktu yang cukup dalam satu harinya baik itu saat pagi ,siang atau pun malam hari.

b. Peningkatan Ketekunan

Pengujian kredibilitas berarti melakukan pengamatan secara lebih cermat dan berkesinambungan. Peneliti membaca seluruh catatan hasil penelitian secara lebih cermat, sehingga diketahui kesalahan dan kekurangannya.

c. Triangulasi

Hal ini dilakukan dengan triangulasi teknik dan triangulasi waktu. Tringulasi teknik dilakukan dengan cara menanyakan hal yang sama dengan teknik yang berbeda.Tringulasi waktu artinya pengumpulan data dilakukan pada berbagai kesempatan, yaitu pagi, siang dan sore hari.

d. Analisis Kasus Negatif

Peneliti melakukan analisis kasus negatif yaitu mencari data yang berbeda atau bertentangan dengan data yang telah ditemukan. Kemudian akan ditanyakan kembali kepada sumber data. Namun jika dari beberapa nara sumber memberikan data yang sama, maka data telah kredibel.

e. Menggunakan Bahan Referensi

Peneliti menggunakan data yang diperoleh dari wawancara, catatan lapangan dan bahan-bahan lain.

\section{Uji Transferability (Validitas Eksternal)}

Transeferability menunjukkan derajad ketepatan atau dapat diterapkannya hasil penelitian ke populasi di mana sampel tersebut diambil. Bila dalam hal ini pembaca memperoleh gambaran yang sedemikian jelasnya tentang sepertiapa hasil penelitian ini dapat diberlakukan, maka laporan ini telah memenuhi standar transeferability (Sugiono, 2008).

\section{HASIL DAN PEMBAHASAN}

\section{Lingkungan Kerja Ramah Perempuan}

Menurut UU No. 13 Tahun 2003 tentang Ketenagakerjaan dalam Pasal 1 ayat (2) menyebutkan, pekerja adalah setiap orang yang mampu melakukan pekerjaan guna menghasilkan barang/jasa baik untuk memenuhi kebutuhan sendiri maupun untuk masyarakat.

Menurut PERMEN Pemberdayaan Perempuan dan Perlindungan Anak No.7 Tahun 2014, tempat kerja adalah ruangan atau lapangan, tertutup atau terbuka, bergerak atau tetap dimana tenaga kerja bekerja, atau sering dimasuki untuk keperluan suatu usaha dan di mana terdapat sumber atau sumber-sumber bahaya.

Ada hubungan timbal balik antara lingkungan kerja dan pekerja didalamnya. Lingkungan kerja yang baik dan mendukung 
dipercaya dapat meningkatkan meningkatkan efektifitas dan produktifitas pekerja. Dewasa ini, telah terjadi perkembangan dan transformasi dalam ketenagakerjaan. Pekerja perempuan bukanlah hal yang aneh bahkan dapat mendominasi suatu jenis pekerjaan tertentu. Perempuan sekarang ini tidak hanya memegang peranan domestik (merawat anak, memasak, mengurus rumah tangga dan lainnya) akan tetapi juga mulai memegang peranan penting di tempat kerja. Dijelaskan pula dalam UU No. 13 Tahun 2003 pada Pasal 77 ayat (2) mengenai perincian waktu kerja yang dapat disimpulkan bahwa wanita pekerja adalah wanita yang sudah menikah, mempunyai anak, bekerja di sektor formal dan bekerja paling tidak 40 (empat puluh) jam dalam satu minggu.

Namun demikian, mayoritas masyarakat tertentu masih membebankan pekerjaan domestik kepada perempuan sehingga pekerja perempuan memiliki fungsi dan peran ganda. Peran ganda adalah ketika wanita mempunyai tugas untuk memelihara keluarga dan menjaga profesionalitas dalam bekerja. Untuk itulah mereka membutuhkan lingkungan kerja yang ramah perempuan sehingga bisa mengakomomodir kedua peranan tersebut.

UNWomendalam laporannya Progress of Women World 2015-2016 menjelaskan tentang sepuluh prioritas aksi publik untuk transformasi ekonomi dan hak perempuan yang pada akhirnya dapat mendukung tercapainya lingkungan ramah perempuan. Sepuluh prioritas ini adalah:

1. Menciptakan pekerjaan yang lebih banyak dan lebih baik bagi perempuan (perempuan dapat menempati level tinggi dalam organisasi).

2. Mengurangi segregasi okupasional dan "gender pay gaps".

3. Menetapkan jaminan pendapatan bagi perempuan (dana sosial, dana perawatan anak, dana pensiun dan lainnya).
4. Mengenali, mengurangi dan meredistribusikan "unpaid and domestic worker" (wanita yang mengerjakan tuga rumah tangga tanpa dibayar).

5. Investasi dalam "gender-responsive sosial service" contohnya fasilitas pelayanan kesehatan.

6. Memaksimalkan sumber daya untuk mencapai kesetaraan substansif.

7. Memberikan dukungan kepada organisasi perempuan terkait hak dan agenda kebijakandi semua tingkatan organisasi.

8. Menciptakan lingkungan yang memungkinkan realisasi hak perempuan.

9. Menggunakan standar Hak Asasi Manusia (HAM) dalam membentuk kebijakan dan perubahan.

10. Mengumpulkan data untuk menilai progresifitas hak sosial dan ekonomi wanita.

Dari sepuluh langkah tersebut, terlihat bahwa adanya kebijakan atau peraturan merupakan salah satu hal yang mendukung terciptanya lingkungan kerja ramah perempuan. Indonesia dalam hal ini telah meratifikasi konvensi ILO terkait gender dan tenaga kerja diantaranya Konvensi No 88 tentang pelayanan ketenagakerjaan, Konvensi No 100 tentang upah yang sama untuk jenis pekerjaan yang sama, dan Konvensi No 111 tentang diskriminasi. Kebijakan terkait perempuan juga dituangkan dalam UU No.13 tahun 2003 tentang ketenagakerjaan, Peraturan Pemerintah No. 33 tahun 2012 serta Peraturan Menteri Pemberdayaan Perempuan dan Perlindungan Anak No 7 tahun 2014 dan sejumlah kebijakan lainnya.

Menurut Deborah dalam Centre Self Assesement for A Woman-Friendly Workplace, suatu lingkungan kerja dikatakan ramah perempuan jika: 


\section{0-85 | HARKAT: Media Komunikasi Islam Tentang Gender dan Anak, 11 (1), 2015}

1. Kesamaan dalam Kompensasi dan Kesempatan Pengembangan Karir

Memberikan kesempatan yang sama terhadap pria dan wanita dalam pengembangan karir adalah elemen fundamental untuk menciptakan lingkungan kerja ramah wanita. Yang tak kalah pentingnya adalah bahwa wanita dapat menempati kedudukan tinggi dalam organisasi. Hal ini berguna sebagai "role model” yang bisa memberikan saran, mendukung dan mewakili kepentingan pekerja wanita.

\section{Retensi}

Menciptakan dan mempertahankan lingkungan kerja yang dapat menghargai dan mengakomodasi kepentingan pekerjanya. Pekerja wanita selain memiliki tugas di tempat kerja juga dituntuk untuk tugas domestik seperti perawatan anak dan rumah.

Hal-hal tersebut diatas dapat terwujud dengan intervensi sebagai berikut :

\section{Kebijakan dan prosedur formal}

Sistem manajemen dan kebijakan ramah perempuan memainkan peranan kritis dalam mencapai efektifitas dan produktifitas para perkerjanya. Kebijakan terkait upah dan promosi, maternitas, perlindungan dari diskriminasi dan kekerasan seksual,ijin kerja untuk anak sakit, cuti bersalin, dan lingkungan kerja ramah laktasi. Kebijakan ini harus membantu pekerja untuk dapat mengintegrasikan tanggung jawab pekerjaan dan kepentingan individu contohnya bagian kerja yang fleksibel.

\section{Norma kerja informal}

Selain peraturan dari pemerintah, normal kerja informal yang berupa kebijakan di tempat kerja juga sangat penting. Kebijakan ini bisa berbeda antara satu tempat kerja dengan yang
lainnya.Norma ini dapat dipelajari dari budaya kerja yang berlaku. Norma tidak tertulis adalah bentul dari budi pekerti, tutur kata ataupun toleransi terhadap individu atau kelompok kerja lainnya.

Pemerintah Indonesia melalui berbagai Kementerian telah menetapkan peraturan terkait tempat kerja diantaranya tentang pembinaan tempat kerja dengan dominasi pekerja wanita (minimal 50 pekerja perempuan). Tempat kerja yang dinilai memenuhi kriteria akan mendapatkan penghargaan dari pemerintah. Yang termasuk dalam kriteria penilaian tersebut adalah sebagai berikut:

- Waktu Kerja dan Istirahat (waktu Kerja Malam)

- Upah Kerja (wages)

- Fasilitas kesejahteraan bagi pegawai perempuan (asrama dan transportasi)

- Fasilitas kesehatan dan sarana lainnya (ruang laktasi, fasilitas ASI ekslusif, istirahat 30 menit untuk pemberian ASI)

- Keselamatan dan kesehatan kerja

- Program pengembangan keterampilan kerja perempuan

(Sumber: Peraturan Menteri Negara Pemberdayaan Perempuan dan Perlindungan Anak Republik Indonesia No 7 Tahun 2014)

Implikasinya Terhadap Peran Serta Pekerja Perempuan dengan Studi Kasus Rumah Sakit Khusus Ibu dan Anak Kota Bandung

Rumah Sakit Khusus Ibu dan Anak (RSKIA) Kota Bandung adalah salah satu tempat pelayanan publik dibawah Pemerintah Kota Bandung. Dengan adanya rumah sakit ini diharapkan dapat memberikan pelayanan kesehatan terhadap pasien khususnya ibu dan anak. Pasien ibu khususnya adalah perempuan hamil, menyusui serta perempuan yang memiliki 
keluhan obstetri ginekologi (masalah kebidanan dan kandungan seperti keguguran, kanker, kb dan lainnya). Pasien anak terdiri dari anak sakit dan anak sehat (salah satunya datang dengan tujuan imunisasi) yang mayoritas diantar oleh orangtuanya terutama ibu. Disini terlihat salah satu peranan perempuan sebagai pekerja domestik (unpaid domestic workers) yaitu sebagai pengurus pekerjaan rumah tangga dan merawat anak (seperti memberikan ASI, melakukan kunjungan imunisasi wajib, serta merawat anak sakit).

Berdasarkan data sekunder yang dikumpulkan oleh peneliti pada bulan September tahun 2015, RSKIA Kota Bandung merupakan rumah sakit tipe B dengan jumlah pekerja lebih dari 300 orang dan sekitar 70\% didominasi oleh pekerja perempuan mulai dari Direktur RS, kepala pelayanan, dokter, bidan, perawat, psikolog, bagian rekam medis, laundri, gizi, apoteker hingga satpam yang bekerja di managemen (kantor), Instalasi Rawat Jalan dan Instalasi Rawat Inap dengan status pegawai tetap maupun pegawai tidak tetap. Pekerja dibagian managemen dan Instalasi Rawat Jalan umumnya bekerja pada pagi hari sedangkan Instalasi Rawat Inap bekerja dengan sistem shift, dimana shift malam jam kerjanya adalah sekitar sebelas jam. Berikut ini adalah hasil penelitian yang dilakukan oleh peneliti di RSKIA Kota Bandung:

1. RSKIA Kota Bandung membuktikan bahwa kehadiran Direktur Rumah Sakit ini telah menghasilkan dampak yang signifikan yaitu persamaan kesempatan menempati posisi tertinggi dalam organisasi serta rolemodelbagi perempuan.

Perempuan seharusnya memiliki perwakilannya di setiap level pengambilan keputusan dalam upaya menghasilkan kebijakan yang memahami porsi perempuan. Tahun 1997, The Beijing Platform for Action menyatakan bahwa sudah banyak forum diskusi NGO seperti negara Australia yang mendiskusikan pentingnya peranan perempuan dalam "setting the agenda" atau terlibat dalam menentukan kebijakan. (Dr. Corner, 1997). Perempuan diharapkan agar mampu berperan dan berpatisipasi dalam semua kegiatan seperti politik, ekonomi, sosial, budaya, pendidikan serta kesamaan dalam menikmati pembangunan. Anita Roddick dalam Helgesen (1990) Female advantage, mengatakan bahwa perempuan dalam memimpin tidak menghiraukan adanya jenjang hierarki, akan tetapi menganggap staf sebagai "teman" yang dihargai, yang disebut Roddick Feminine Principles. Hal ini adalah salah satu yang diharapkan dari kepemimpinan perempuan agar meningkatkan performa pekerja baik secara psikologi ataupun mental.

Lebih jauh lagi, keterlibatan perempuan dalam partisipasinya di decision-making forums akan mendukung terciptanya prioritas pengembangan manusia (human development) termasuk kadar pemenuhan nutrisi dan gizi, kesehatan bayi dan anak, maupun kebutuhan khusus bagi pekerja perempuan.

Menurut laporan UN Women tahun 2015-2016, Community Forestry Institutions telah menyatakan dalam penelitiannya bahwa Gujarat (India) mulai menerima aspirasi perempuan untuk hadir di level pengambilan kebijakan yang berdampak kepada terciptanya lingkungan yang mendorong perempuan berkontribusi aktif di lingkungan kerjanya (UN Women, 2015).

Oleh karena itu, RSKIA dianggap sudah membuktikan adanya keterlibatan perempuan dalam organisasi untuk menentukan kebijakan. 


\section{2-85 | HARKAT: Media Komunikasi Islam Tentang Gender dan Anak, 11 (1), 2015}

2. Adanya Konselor ASI, ruangan laktasi, internal workshop, serta norma informal di RSKIA kota Bandung telah mengimbangi dampak negatif beban kerja berat bagi perempuan.

Pekerja perempuan mempunyai peran ganda. Selain sebagai pekerja di bidangnya, perempuan juga dianggap memiliki keharusan untuk melakukan pekerjaan domestik. Hal inilah yang mengakibatkan perempuan memiliki beban kerja yang berat (Molly, 2011). Tidak hanya berdampak pada pekerja namun juga instansi tempat ia bekerja. Apalagi petugas kesehatan yang melayani ibu hamil memiliki sistem kerja shift yang pelayanannya selalu harus siap siaga 24 jam (Julie, 2015).

Peneliti sempat mengutip pernyataan saat sesi wawancara salah satu bidan RSKIA Kota Bandung:

"Saya memiliki tugas jaga pada pagi, siang maupun malam hari. Sepintas biasa saja, tapi yang sangat memberatkan adalah tugas jaga Shiftt Malam. Saya harus bekerja mulai dari jam 8 malam sampai 7 pagi dan keadaan yang tidak terduga membuat saya tidak istirahat semalaman. Pulangnya, saya sudah harus segera mengerjakan pekerjaan di rumah baik mengurus anak, memasak, keperluan suami apalagi bayi saya yang membutuhkan ASI.”

Peran ganda yang dibebankan kepada pekerja perempuan tersebut telah membatasi ruang bagi perempuan mengembangkan kualitas dirinya bahkan tidak hanya itu berdampak kepada hasil kerja yang tidak maksimal (Rebecca, 2011). Beberapa pasien ibu menyusui (wanita pekerja) yang datang ke RSKIA Kota Bandung mengakui mereka tidak lagi memberikan ASI eksklusif dikarenakan terlalu sibuk bekerja. Padahal pemerintah Indonesia telah mengeluarkan Peraturan Pemerintah No. 33 tahun 2012 berkenaan dengan Jaminan

PelaksanaanPemberian ASI Eksklusif dikarenakan ASI eksklusif memegang peranan penting antara lain:

- Menyelamatkan 1-2 juta jiwa setiap tahun.

- Mengurangi persentase kematian akibat Infeksi Pernapasan Akut dan diare antara $50-95 \%$.

- Meningkatkan efektivitas imunisasi secara signifikan.

- Mengurangi kebutuhan akan cairan pengganti cairan tubuh yang hilang lebih dari 50\%.Secara otomatis menekan tingkat penularan HIV dari ibu ke anak dengan perkiraanpersentase antara 10-20\%.Menekan jumlah anak yang ditinggalkan orang tuanya di rumah sakit dan memperkuat ikatan protektif antara ibu dan anak.

- Mendorong pertumbuhan dan menyediakan sebagian besar kebutuhan nutrisi bayi. (UNICEF, 2010)

Menyadari urgensi dan manfaat pemberian ASI, RSKIA Kota Bandung berperan aktif sebagai tempat pelayanan publik yang peduli ASI. Rumah sakit dilengkapi dengan ruangan konseling menyusui. Beberapa petugas kesehatan rumah sakit (dokter, bidan ataupun perawat) disertakan dalam pelatihan ASI sehingga mereka menjadi tenaga ahli yang terampil dengan membagikan pendidikan mereka tersebut kepada seluruh pihak Rumah Sakit lewat internal workshop. Pekerja diajari bagaimana menemukan jalan keluar dari hambatan pemberian ASI eksklusif yaitu tidak tersedianya tempat penitipan bayi dan anak di Rumah Sakit menjadikan pekerja perempuan tidak bisa membawa ASI secara langsung pada saat bekerja. Konselor ASI dan internal workshopmemberikan 


\begin{tabular}{|c|c|c|c|}
\hline Tempat & Suhu & Durasi & Keterangan \\
\hline Meja & $\begin{array}{l}\text { Suhu ruangan } \\
\left(\max -25^{\circ} \mathrm{C}\right)\end{array}$ & 6-8 jam & $\begin{array}{l}\text { Wadah harus ditutupi dan dijaga sedingin mungkin, } \\
\text { bila perlu dibalut dengan handuk dingin. }\end{array}$ \\
\hline $\begin{array}{l}\text { Cooler bag } \\
\text { tertutup }\end{array}$ & $-15-4^{\circ} \mathrm{C}$ & 24 jam & $\begin{array}{l}\text { Pastikan es batu menyentuh wadah ASI sepanjang } \\
\text { waktu, hindari membuka Cooler bag }\end{array}$ \\
\hline Lemari es & $4^{\circ} \mathrm{C}$ & 5 hari & Simpan ASI pada bagian belakang lemari es \\
\hline \multicolumn{3}{|l|}{ Freezer } & \multirow{4}{*}{$\begin{array}{l}\text { Simpan ASI pada bagian belakang freezer di mana } \\
\text { suhu berada dalam kondisi paling stabil. ASI yang } \\
\text { disimpan lebih lama dari waktu yang dianjurkan } \\
\text { tetap aman, tetapi kandungan lemak mulai } \\
\text { terdegradasi sehingga kualitasnya menurun. }\end{array}$} \\
\hline $\begin{array}{l}\text { Freezer dengan } \\
\text { lemari es } 1 \text { pintu }\end{array}$ & $-15^{\circ} \mathrm{C}$ & $2 \mathrm{mgg}$ & \\
\hline $\begin{array}{l}\text { Freezer dengan } \\
\text { lemari es } 2 \text { pintu }\end{array}$ & $-18^{\circ} \mathrm{C}$ & $3-6$ bln & \\
\hline $\begin{array}{l}\text { Freezer dengan } \\
\text { pintu di atas }\end{array}$ & $-20^{\circ} \mathrm{C}$ & 6-12 bln & \\
\hline
\end{tabular}

Sumber Gambar 1.2 : www.idai.or.id

pengetahuan bahwa ASI eksklusif tetap bisa diberikan dengan cara memompa ASI dan menyimpannya. Adapun cara penyimpanan ASI ekslusif sebenarnya tidak terlalu sulit, seperti tercantum dalam Gambar 1.2:

Pendidikan tentang cara menyimpan ASI Ekslusif inilah yang nantinya mengedukasi pekerja perempuan antara lain bahwa lama pengawetan ASI (tahan 6 jam-8 di suhu kamar, tahan 2 minggu di kulkas satu pintu, 3-6 bulan dalam kulkas satu pintu, 3-6 bulan dengan kulkas dua pintu pada suhu $-18^{\circ} \mathrm{C}$ dan $6-12$ bulan dalam freezer khusus yang sangat dingin $-20^{\circ} \mathrm{C}$ ). mampu dipertimbangkan dari segi ekonomis (gratis dan terbaik dibandingkan susu formula) dan efisiensi bahwa pemberiaan ASI bisa diberikan meski sang ibu sedang bekerja. (AIMI, 2013)

3. Persamaan upah kerja (equal pay) bagi pekerja perempuan di RSKIA Kota Bandung telah menciptakan lingkungan 'no gender pay gaps'

Setiap pekerja RSKIA Kota Bandung baik perempuan maupun lelaki dengan status, beban dan tanggung jawab yang sama di tempat kerja telah mendapatkan persamaan upah (Equal Work, Equal Pay). Hal ini sesuai dengan konvensi ILO No 100 yang telah diratifikasi Indonesia sejak tahun 1958 (ILO, 2015). Selain itu, pekerja perempuan yang sedang cuti bersalin juga tetap mendapatkan upahnya yaitu gaji pokok penuh serta tambahan jasa medis sebesar duapertiga dari pendapatan seharusnya. Hal ini telah sesuai dengan standar internasional tentang ketenagakerjaan yaitu setiap pekerja perempuan berhak atas cuti bersalin dan tetap mendapatkan upahnya sebagaimana biasanya minimal duapertiga dari upah seharusnya.

Ketiga hal yang telah disebutkan diatas mendukung terciptanya lingkungan kerja ramah perempuan. Akan tetapi, lingkungan kerja ramah perempuan di Indonesia masih banyak yang harus diperbaiki. Penelian yang telah dilakukan di RSIA Kota telah menunjukkan bahwa walaupun sudah banyak aspek yang mendukung lingkungan kerja ramah perempuan, terdapat faktor lain yang semestinya diperhatikan dan diperbaiki diantaranya adalah mengenai waktu cuti. Pekerja perempuan yang memiliki status pegawai tetap mendapatkan kesempatan cuti bersalin selama 3 bulan sesuai dengan UU No.13 tahun 2003 tentang Ketenagakerjaan. Akan tetapi, pekerja dengan status pegawai tidak tetap hanya diberikan kesempatan cuti bersalin selama 40 hari hingga 2 bulan. Hal ini menunjukaan masih adanya perbedaan diantara sesama pekerja yang tentunya dapat menimbulkan ketidakpuasan dan diskriminasi diantara sesama pekerja. 


\section{PENUTUP}

Dari penelitian ini dapat disimpulkan bahwa Lingkungan kerja dan pekerja memiliki hubungan timbal balik yang saling mempengaruhi baik secara positif maupun negatif. Lingkungan kerja ramah perempuan memang tidak memiliki batasan secara pasti namun dapat tercipta melalui kondisi-kondisi dimana hak-hak dan suara perempuan dihargai baik dalam kesempatan kerja, posisi kerja, upah, waktu kerja, waktu istirahat, tersedianya fasilitas ramah perempuan dan kebijakan ramah perempuan. Tempat kerja yang mengaplikasikan lingkungan kerja ramah perempuan dapat mengkompensasi beban kerja, meningkatkan produktifitas dan performa karyawan sehingga dapat meningkatkan kinerja dan pelayanan sehingga berdampak positif pada transformasi sosial ekonomi ke arah yang lebih baik.

\section{DAFTAR PUSTAKA}

Sugiyono. 2008.Memahami Penelitian Kualitatif. Alfabeta: Bandung.

AIMI. (2013). Lingkungan Kerja Ramah Laktasi: Pedoman Untuk Perusahaan. www.betterwork.org/Indonesia

Chattopadhyay, Molly. (2011). Women Workers in the Mica Industry: A Case Study. Indian Journal of Gender Studies 18(3) 341-364. 2011. http://ijg.sagepub.com

Deborah and Sara. (2001). Centre SelfAssessment For A Woman-Friendly Workplace. CGIAR Gender and Diversity Program Working Paper No. 29. http://pvawhub.whwest.org.au/centre-selfassessment-for-a-woman-friendlyworkplace/

Dr. Corner, Lorraine. (1997). Women's Participation in Decision-Making and LeadershipA Global Perspective. dipublikasikan oleh ACWF and ICAROAP.

(http://iknowpolitics.org/sites/default/files/decisi on-making26leadership_global.pdf)

ILO Travail Legal Database 2013 (https:/www.ilo.org/dyn/travail/travmain.h ome), diakses pada 22 September 2015.

Julie and Peter (2015). Flexible working and work-life balance: midwives' experiences and views. Work, employment and society 2015, Vol. 29(5) 757-774. www.wes.sagepub.com

Peraturan Menteri Negara Pemberdayaan Perempuan dan Perlindungan Anak Republik Indonesia No 7 Tahun 2014 Tentang Panduan Penilaian Perusahaan Pembina Terbaik. (www.hukumonline.com) diakses pada tanggal 22 September 2015.

Peraturan Pemerintah No. 33 tahun 2012 tentang Pemberian ASI Eksklusif. (www.depkes.go.id) diakses pada tanggal 22 Setember 2015.

Rebecca et al (2011). Actigraph Estimates of the Sleep of Australian Midwives: The Impact of Shift Work. Biological Research for Nursing 15(2)

191-199. www.brn.sagepub.com

Statistik Indonesia 2015. (www.bps.go.id), diakses pada tanggal 22 Setember 2015

Undang-Undang Ketenagakerjaan No. 13 Tahun 2003. (www.hukumonline.com), diakses pada tanggal 22 September 2015

UNICEF and the Global Strategy on Infant and Young Child Feeding (2010) . Memahami Masa Lalu Perencanaan Masa Depan. http://www.unicef.org/nutrition/files/Final ReportonDistribution.pdf 


\section{HARKAT: Media Komunikasi Islam Tentang Gender dan Anak, 11 (1), 2015| 85-85}

UNWoman (2015). Progress of The World Women 2015-2016, Transforming Ekonomies Realizing Rights. http://progress.unwomen.org

\section{Wawancara}

Lisa, S.Pd. (2015, September 20). Wawancara mendalam

Rochiach, Siti, Am.Keb, et al. (2015, September 20). Wawancara mendalam

Rahmanita, Hesti, dr. (2015, September 21). Wawancara mendalam 